\title{
Graphene based Electrocatalysts for DMFCs
}

\author{
Ehtsham Sarwar, M Irfan Raza, and Naseem Iqbal
}

\begin{abstract}
Fuel cell is a device that generates electricity by a chemical reaction. Recently carbon black was commonly used as a support for fuel cells but their properties were not satisfactory for the better electrocatalytic activity and stability. In the recent years graphene is introduced as a carbon support that can replace the carbon black because it provides better resistance towards corrosion, high surface area, high mechanical strength, high conductivity and potential low manufacturing cost. Commonly platinum based electrode materials were used in DMFCs, but high cost of platinum limited the commercialization of DMFCs. In this paper graphene supported Pt-based materials and graphene supported non-Pt metals are compared. Electrocatalytic activity of the electro-catalysts was compared through the comparison of $\mathrm{I}_{\mathrm{F}} / \mathrm{I}_{\mathrm{R}}$ ratio and charge transfer resistance $\left(R_{c t}\right)$ obtained from the cyclic voltammetry.
\end{abstract}

Keywords---Electrocatalysts, DMFCs, Graphene, Electrocatalytic activity, Stability

\section{INTRODUCTION}

Due to increase in the energy demands day by day, continuous and rapid depletion of fossil fuels along with the increase in the concentration of greenhouse gases encourages the researchers to do research into the development of alternative and greener energy sources. As fuel cells have almost zero emissions of harmful greenhouse gases like $\mathrm{So}_{\mathrm{x}}$, $\mathrm{No}_{\mathrm{x}}$ and $\mathrm{Co}_{2}$, which attracts the scientists and engineers to do research in the field of fuel cells. Basically fuel cell is an electrochemical device that converts the chemical energy into electrical energy. Fuel cell is consisting of an anode, cathode and an electrolyte. Fuel cells have higher fuel conversion and electrical efficiency as compare to the conventional combustion. There are various types of fuel cells, which includes proton exchange membrane fuel cells (PEMFCs), direct methanol fuel cells (DMFCs), phosphoric acid fuel cells (PAFCs), solid oxide fuel cells (SOFCs), alkaline fuel cells (AFCs), molten carbonate fuel cells (MCFCs) and microbial fuel cells (MFCs). Fuel cells are very suitable for future transport, stationary and portable power applications along with the environmental benefits. Direct methanol fuel cells (DMFCs) are very effective in oxidizing methanol in the anodes and reducing oxygen in the cathodes.

The authors are from USPCAS-E NUST Islamabad, Pakistan. Email Address: shamiehtsham@yahoo.com (Ehtsham).
Catalyst is the main factor which determines the efficiency, activity and overall cost of the fuel cell device. Platinum is the most widely used electro-catalysts in the direct methanol fuel cells (DMFCs). Platinum catalysts are very attractive for DMFCs, but they are very expensive, poor utilization efficiency and limited platinum availability [1-4].

To develop a catalyst having better catalytic activity and stability, researchers are focused on the development of $\mathrm{Pt}$ based catalysts for the oxidation of methanol in DMFCs. On the other hand to further improve the electrochemical activity and stability, various carbon materials have been reported as a support for fuel cells, such as carbon nanofiber, carbon nanotubes and mesoporous carbon. Graphene is a twodimensional one-atom-thick planar sheet of $\mathrm{sp}^{2}$ bonded carbon atoms; Compared with other carbon materials graphene is an ideal electrode material due to its high surface area, good thermal stability, unique graphitized basal planer structure, excellent conductivity and lower manufacturing cost. Production cost of graphene nanosheets is lower as compare to the other carbon nanotubes [5-7]. Graphene is a promising material for its potential applications in various fields such as solar cells, super capacitor and fuel cells [14].

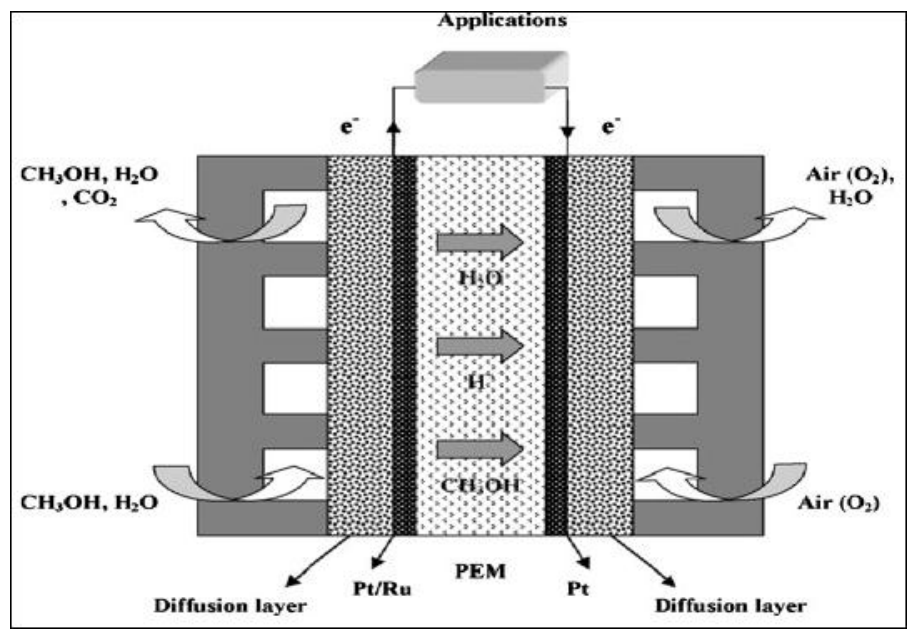

Fig.1 Schematic diagram of DMFC [13]

\section{SYNTHESIS OF MATERIALS}

Graphene nanoplate-Pt composite was synthesized by using a soft chemical method to load platinum nanoparticles on graphene nanoplates. In a typical method ethylene glycol and $\mathrm{Pt}(\mathrm{No} 3) 2$ solution were added to the graphene nanoplates 
dispersion and stirring is performed for $15 \mathrm{~min}$. After this the resulting mixture was then transferred to Teflon-lined stainless autoclave and sealed tightly, autoclave is then heated to $120^{\circ} \mathrm{C}$ for 12 hours. After performing the solvothermal treatment, the nanocomposite is named as GNP/Pt and various cycles of centrifugation is performed, washed and then drying is performed in air at $60^{\circ} \mathrm{C}$ overnight [7]. Graphene-CeO2 hybrid support for Pt nanoparticles was synthesized, graphene oxide was prepared by modified hummer's method. CeO2-GN hybrid support was prepared by taking a specific amount of cerium nitrate and distribute in graphene oxide solution. Then adjust the $\mathrm{pH}$ of solution to 10 by using the ammonia. After this temperature is increased to $80^{\circ} \mathrm{C}$ for 6 hours. Then mixture is transferred into an autoclave for the hydrothermal treatment at $160^{\circ} \mathrm{C}$ for 4 hours. Finally product was collected after filtering, washed with ethanol and water several times and then dried in a vacuum oven at $50^{\circ} \mathrm{C}$. Pt$\mathrm{CeO} 2 / \mathrm{GN}$ was prepared by taking $45.2 \mathrm{mg}$ of $\mathrm{CeO} 2 / \mathrm{GN}$ and dispersed into $50 \mathrm{ml}$ ethylene glycol and ultrasonification is performed for one hour. After this $30 \mathrm{mg}$ of $\mathrm{H} 2 \mathrm{PtCl} 6$ was added, and set the $\mathrm{pH}$ of the solution to 9 with the addition of potassium hydroxide drop wise. Then stirred the mixture for 4 hours at $90^{\circ} \mathrm{C}$ and $\mathrm{Pt}-\mathrm{CeO} 2 / \mathrm{GN}$ electrocatalyst was collected [8]. Pt-SiO2/Graphene nanocomposites was synthesized using solvothermal method, graphene oxide was prepared by modified Hummer's method. Pt-SiO2/Graphene catalyst was prepared by taking the $10.2 \mathrm{ml}$ of $\mathrm{H} 2 \mathrm{PtCl} 6$ solution and inserted the solution into $20 \mathrm{ml} \mathrm{DMF}$, containing graphene oxide $(50 \mathrm{mg})$. Then stirring is performed, after this $0.15 \mathrm{~g}$ of $\mathrm{KI}$ and certain amount of TEOS were added into the solution and stirring is performed for one hour at room temperature. After this mixture was shifted into a $50 \mathrm{ml}$ Teflon-lined stainless steel autoclave and heated at $130^{\circ} \mathrm{C}$ for 5 hours. The solid product was collected after performing various cycles of centrifugation, washed with ultrapure water and ethanol several times and then dried for $24 \mathrm{~h}$ at $60^{\circ} \mathrm{C}$. Three different products were obtained and named as $\mathrm{Pt}-\mathrm{SiO} 2 / \mathrm{G}-1$, Pt$\mathrm{SiO} 2 / \mathrm{G}-2$ and Pt-SiO2/G-3 for the initial amounts of 11.2, 18.6 and $31 \mathrm{mg}$ TEOS. Similarly $\mathrm{SiO} 2 / \mathrm{G}$ nanocomposite was also prepared in the same way as the composite of $\mathrm{Pt}-\mathrm{SiO} / \mathrm{G}$ but in the absence of $\mathrm{H} 2 \mathrm{PtCl} 6$ for comparison, while a sample of $\mathrm{Pt}$ on graphene was also prepared without TEOS) [15]. PtCo nanoparticles supported on EG was synthesized. In order to prepare the EG, the natural graphite flakes were dipped in $\mathrm{HClO} 4$ for $10 \mathrm{~min}$, filtered and produced by using muffle furnace under $900-1000^{\circ} \mathrm{C}$. PtCo/EG catalyst was synthesized by the solution-phase reduction method. In this method a total of $20 \%$ metal weight of PtCo (with atomic ratio 1:1) catalyst was prepared by taking $29.44 \mathrm{mg}$ of expanded graphite and dispersed in the solution of DI water $(10 \mathrm{ml})$ and ethyl alcohol $(10 \mathrm{ml})$ in an ultrasonic bath for 30 min, after this $1.0 \mathrm{ml}$ of $0.0289 \mathrm{M} \mathrm{H} 2 \mathrm{PtCl} 6$ solution and 0.1 $\mathrm{ml}$ of $0.289 \mathrm{M}$ cobaltous chloride solution were mixed in the solution and stirring is performed for $10 \mathrm{~min}$. Then $\mathrm{pH}$ value was adjusted to 10 using $\mathrm{NaOH}(0.5 \mathrm{M})$ solution, and then ethylene glycol were added and stirring is performed for 20 min. After this solution was stirred under the flow of argon at $140^{\circ} \mathrm{C}$ for $3 \mathrm{~h}$. The resulting product was filtered, washed with DI water and ethanol several times, and finally dried for $24 \mathrm{~h}$ at $70^{\circ} \mathrm{C}$ in a vacuum oven. Similarly preparation of $\mathrm{PtCo} / \mathrm{MWCNT}$ catalyst was completed following the same procedure [9]. Co-Ni-decorated graphene electrocatalyst was synthesized. Graphene oxide was prepared by a modified hummer's method. CoNi loaded graphene was obtained by taking a round flask, graphene oxide powder $(300 \mathrm{mg}$ ) were dispersed in $400 \mathrm{ml}$ distilled water and sonicated for $40 \mathrm{~min}$. After this hydrazine hydrate $(0.5 \mathrm{ml})$ was added to the solution. Certain amount from cobalt acetate and nickel acetate were individually dissolved in the water and mixed with graphene oxide suspension. In order to study the loading weight $0.1,0.2$ and $0.4 \mathrm{~g}$ from each salt were utilized. To study the influence of metallic nanoparticles composition, the loading weight was fixed at $0.4 \mathrm{~g}$, the utilized NiAc:CoAc amounts (g:g) were 0.0:0.4, 0.1:0.3, 0.2:0.2 and 0.4:0.0. After this slurry was refluxed for $10 \mathrm{~h}$ at $150^{\circ} \mathrm{C}$. After this step the solution was filtered and filter cake was washed with water various times. Then dried the sample at $80^{\circ} \mathrm{C}$ for one night under the vacuum oven. After this calcined the obtained product under argon atmosphere for $2 \mathrm{~h}$ at $850^{\circ} \mathrm{C}$ [10]. Simultaneous $\mathrm{Pt}$ deposition and nitrogen doping electrocatalyst has been synthesized. GO was prepared from flaky graphite powder by using a modified Hummers method. For the preparation of electrocatalyst, GO solution was mixed with $9.2(\mathrm{ml})$ of $\mathrm{H} 2 \mathrm{PtCl} 6,0.1550$ gram of sodium citrate ( $\mathrm{Na} 3 \mathrm{C} 6 \mathrm{H} 5 \mathrm{O} 7)$ and 8 grams of urea $(\mathrm{CH} 4 \mathrm{~N} 2 \mathrm{O})$ and ultrasonicated for 2 hours. Then $8 \mathrm{ml}$ of $\mathrm{CH} 2 \mathrm{O} 2$ was added. After this, the mixture was sealed in a 100 (ml) Teflon-lined autoclave for 12 hours at $180^{\circ} \mathrm{C}$. Then leave the autoclave to cool down to room temperature naturally and reactant was washed several times with water and ethanol in order to remove impurities. Sample was dried under vacuum oven to obtain final product (Pt/N-Graphene).For the preparation of $\mathrm{Pt} / \mathrm{Graphene}$, the same procedure was followed in the absence of urea [11]. Reduced graphene oxide supported FePt alloy nanoparticles are synthesized by following two steps. In the first step $24 \mathrm{mg}$ of $\mathrm{K} 4 \mathrm{Fe}(\mathrm{CN}) 6.3 \mathrm{H} 20$ is dissolved in $24 \mathrm{~mL} \mathrm{DI}$ water. Then the solution is mixed into $6 \mathrm{~mL}$ GO solution under stirring. After this solution is ultrasonicated for $30 \mathrm{~min}$ and then transferred into a $40(\mathrm{~mL})$ autoclave and maintained at $180^{\circ} \mathrm{C}$ for 24 hours. Then the product was washed with ethanol and water several times and dried for $12 \mathrm{~h}$ at $60^{\circ} \mathrm{C}$ under vacuum. While in the second step $60(\mathrm{mg})$ of the hydrothermal products are mixed into $60 \quad(\mathrm{~mL})$ $\mathrm{H} 2 \mathrm{PtCl} 6.3 \mathrm{H} 2 \mathrm{O}$ solution. After this ultrasonication is 
performed for $30 \mathrm{~min}$ and then evaporated at $80^{\circ} \mathrm{C}$ under stirring. After drying, the obtained powder was then inserted into the tube furnace and sintered for $2 \mathrm{~h}$ in $\mathrm{H} 2 / \mathrm{Ar}$ at $120^{\circ} \mathrm{C}$ with the heating rate of about $1^{\circ} \mathrm{C} / \mathrm{min}$ to obtain the final product (FePt/RGO). Similarly for comparison $6 \mathrm{~mL}(\mathrm{GO})$ solution is mixed with $60 \mathrm{~mL}(\mathrm{H} 2 \mathrm{PtCl}) .3 \mathrm{H} 2 \mathrm{O}$ solution. After this ultrasonication is performed for $30 \mathrm{~min}$ and stirring is performed at $80^{\circ} \mathrm{C}$. After this calcination is performed at

$120^{\circ} \mathrm{C}$ in $\mathrm{H} 2 / \mathrm{Ar}$ atmosphere to obtain the final product (Pt/RGO) [12].

\section{ELECTROCHEMICAL PROPERTIES}

Basically there are three main factors, that can be considered in order to observe the electrocatalytic activity of the synthesized electrocatalyst named as ECSA (Electrochemical surface area), $\mathrm{I}_{\mathrm{F}} / \mathrm{I}_{\mathrm{R}}$ ratio and $\mathrm{R}_{\mathrm{ct}}$ (charge transfer resistance).

TABLE I

ELECTROCHEMICAL PROPERTIES OF VARIOUS ELECTROCATALYSTS

\begin{tabular}{|c|c|c|c|c|c|c|}
\hline Electrode & $\begin{array}{l}\text { ECSA } \\
\left(\mathrm{m}^{2} \mathrm{~g}^{-1}\right)\end{array}$ & $\mathrm{I}_{\mathrm{F}}\left(\mathrm{mAcm}^{-2}\right)$ & $\mathrm{I}_{\mathrm{R}}\left(\mathrm{mAcm}^{-2}\right)$ & $\mathrm{I}_{\mathrm{F}} / \mathrm{I}_{\mathrm{R}}$ ratio & $\mathrm{R}_{\mathrm{ct}}(\mathrm{ohm})$ & References \\
\hline $\mathrm{GNP} / \mathrm{Pt}$ & 63.0 & 57.7 & 47.5 & 1.21 & 473.5 & [7] \\
\hline $\mathrm{XC}-72 / \mathrm{Pt}$ & 33.7 & 17.5 & 15.1 & 0.86 & 4.5 & [7] \\
\hline $\mathrm{RGO} / \mathrm{Pt}$ & 53.6 & 44.2 & 52.1 & 0.85 & 15.0 & [7] \\
\hline $\mathrm{Pt} / \mathrm{GN}$ & 53.9 & 185.8 & - & 1.37 & - & [8] \\
\hline $\begin{array}{c}\mathrm{Pt7} \% \\
\mathrm{CeO}_{2} / \mathrm{GN}\end{array}$ & 66.4 & 440.1 & - & 1.48 & - & [8] \\
\hline $\begin{array}{c}\mathrm{Pt} 5 \% \\
\mathrm{CeO}_{2} / \mathrm{GN} \\
\end{array}$ & 62.5 & 324.8 & - & 1.45 & - & [8] \\
\hline $\begin{array}{c}\mathrm{Pt} 3 \% \\
\mathrm{CeO}_{2} / \mathrm{GN}\end{array}$ & 59.1 & 279.5 & - & 1.41 & - & [8] \\
\hline $\mathrm{Pt} 10 \% \mathrm{CeO}_{2} / \mathrm{GN}$ & 45.3 & 402.9 & - & 1.35 & - & [8] \\
\hline $\mathrm{Pt}-\mathrm{SiO}_{2} / \mathrm{G}-2$ & 87.19 & 1047 & 1010 & 1.04 & - & [15] \\
\hline $\mathrm{Pt}-\mathrm{SiO}_{2} / \mathrm{G}-3$ & 51.30 & 320 & 313 & 1.02 & - & [15] \\
\hline $\mathrm{Pt}-\mathrm{SiO}_{2} / \mathrm{G}-1$ & 62.53 & 520 & 483 & 1.08 & - & [15] \\
\hline $\mathrm{Pt} / \mathrm{G}$ & 41.29 & 248 & 225 & 1.10 & - & [15] \\
\hline $\mathrm{Pt} / \mathrm{C}$ & 38.87 & 320.75 & - & 0.74 & - & [9] \\
\hline $\mathrm{PtCo} / \mathrm{EG}$ & 55.75 & 525.08 & - & 1.17 & - & [9] \\
\hline $\mathrm{PtCo} / \mathrm{MWCNT}$ & 44.83 & 474.59 & - & 1.14 & - & [9] \\
\hline $\mathrm{Co}-\mathrm{Gr}$ & - & - & - & - & 5.128 & {$[10]$} \\
\hline $\mathrm{Co}_{0.2} \mathrm{Ni}_{0.2}-\mathrm{Gr}$ & - & - & - & - & 2.824 & {$[10]$} \\
\hline $\mathrm{Ni}-\mathrm{Gr}$ & - & - & - & - & 5.788 & [10] \\
\hline Pt-G & 65.60 & - & - & 1.0 & - & [11] \\
\hline Pt-NG & 78.55 & - & - & 1.1 & - & [11] \\
\hline $\mathrm{Pt} / \mathrm{RGO}$ & - & - & - & 1.75 & - & [12] \\
\hline $\mathrm{FePt} / \mathrm{RGO}$ & - & - & - & 2.26 & - & [12] \\
\hline
\end{tabular}

It has been concluded that GNP/Pt has better electrocatalytic activity and stability, since GNP/Pt has higher value of $I_{F} / I_{R}$ ratio and smaller value of charge transfer resistance as compare to the $\mathrm{RGO} / \mathrm{Pt}$ and $\mathrm{XC}-72 / \mathrm{Pt}$ for methanol oxidation [7].

Pt- $\mathrm{CeO}_{2} / \mathrm{GN}$ electrocatalyst has been prepared using two different methods consisting of hydrothermal method and impregnation-chemical reduction method. It has been concluded that the largest ESA and $\mathrm{I}_{\mathrm{F}} / \mathrm{I}_{\mathrm{R}}$ ratio with the $\mathrm{CeO}_{2}$ content of $7 \mathrm{wt} \%$ had the best performance as compare to the other catalysts for the oxidation of methanol [8].

$\mathrm{Pt}-\mathrm{SiO}_{2} / \mathrm{G}$ electrocatalyst were synthesized successfully by a one-pot method under solvothermal condition. The electrochemical measurements showed that the $\mathrm{Pt}-\mathrm{SiO}_{2} / \mathrm{G}-2$ had the highest value of ECSA and performs best as compare to the other catalysts for the electrooxidation of methanol. It 
has been concluded that for this catalyst, methanol electrooxidation was improved by 4.2 times and the stability of this catalyst also improved by 1.64 times as compare to the $\mathrm{Pt} / \mathrm{G}$ catalysts [15].

$\mathrm{PtCo} / \mathrm{MWCNT}$ and PtCo-EG catalysts were successfully synthesized by using solution-phase reduction method. It has been concluded that PtCo nanoparticles supported on EG showed higher value of ECSA, larger value of $I_{F} / I_{R}$, more stability and excellent electrocatalytic activity towards the methanol oxidation as compare to the $\mathrm{Pt} / \mathrm{C}$ and $\mathrm{PtCo} / \mathrm{MWCNT}$ catalysts [9].

Co-Ni decorated graphene electrocatalysts were successfully synthesized. It has been concluded that better chemical corrosion resistance and high electrocatalytic activity toward methanol electrooxidation can be obtained through the $\mathrm{Co}-\mathrm{Ni}$ decorated graphene electrocatalysts. In order to produce solid solution Co-Ni alloy nanoparticle, calcination of resultant decorated graphene in argon atmosphere is a very important step. It has been observed that $\mathrm{Co}_{0.2} \mathrm{Ni}_{0.2}$-decorated graphene showed the best results as compare to the other CoNi-decorated graphene metal loadings [10].

Pt-NG and Pt-G has been synthesized successfully. It has been observed that Pt-NG shows better electrocatalytic activity towards methanol considering both the mass and specific activities as compare to the Pt-G [11].

$\mathrm{Pt} / \mathrm{RGO}$ and $\mathrm{Fe}-\mathrm{Pt} / \mathrm{RGO}$ has been synthesized and concluded that $\mathrm{Fe}-\mathrm{Pt} / \mathrm{RGO}$ shows higher value of $\mathrm{I}_{\mathrm{F}} / \mathrm{I}_{\mathrm{R}}$ ratio, which means that $\mathrm{Fe}-\mathrm{Pt} / \mathrm{RGO}$ have better electrocatalytic activity as compare to the Pt/RGO [12].

\section{IV.CONCLUSIONS}

Commercialization of fuel cells is limited due to high cost of platinum and low stability of carbon supports. Graphene is a promising support material or catalyst materials in DMFCs which play a very important role for the oxidation of methanol in terms of electro-catalytic activity and stability. $I_{F} / I_{R}$ and $R_{c t}$ are the main factors which are obtained from cyclic voltammetry are responsible for the showing of electrocatalyst performance. A higher value $I_{F} / I_{R}$ and the smaller value of $R_{c t}$ indicate better oxidation of methanol.

1. It has been observed that when GNP/Platinum was synthesized, it shows $\mathrm{I}_{\mathrm{F}} / \mathrm{I}_{\mathrm{R}}$ ratio equivalent to 1.21 .

2. When the Pt-7\%CeO2/GN was synthesized, it shows $\mathrm{I}_{\mathrm{F}} / \mathrm{I}_{\mathrm{R}}$ ratio equivalent to 1.48 .

3. When $\mathrm{Pt}-\mathrm{SiO}_{2} / \mathrm{G}-2$ electrocatalyst was synthesized, it shows ECSA $\left(\mathrm{m}^{2} \mathrm{~g}^{-1}\right)$ value equivalent to 87.19 which is much better than the $\mathrm{Pt} / \mathrm{G}$.

4. Similarly when PtCo/EG electro-catalyst was synthesized, it shows $\mathrm{I}_{\mathrm{F}} / \mathrm{I}_{\mathrm{R}}$ ratio equivalent to 1.17 .
5. When $\mathrm{Co}_{0.2} \mathrm{Ni}_{0.2} \mathrm{Gr}$ was synthesized, it shows minimum charge transfer resistances that were 12.09, 3.168 and 2.824 at different methanol concentrations of 1.0, 2.0 and 3.0 as compare to the other CoNi-Gr metal loadings.

6. When Pt-NG electrocatalyst was synthesized, it shows higher ECSA value and larger $I_{F} / I_{R}$ value.

7. Similarly when $\mathrm{Fe}-\mathrm{Pt} / \mathrm{RGO}$ electrocatalyst was synthesized, it shows higher $I_{F} / I_{R}$ value that was 2.26.

Comparing seven different electrocatalyst, it was observed that $\mathrm{Co}_{0.2} \mathrm{Ni}_{0.2}$ - $\mathrm{Gr}$ has showed significant results towards methanol oxidation as compare to the other four electrocatalyst reported earlier. $\mathrm{Co}_{0.2} \mathrm{Ni}_{0.2}$-Gr electrocatalyst has good stability and non-precious electrocatalyst. It is recommended that instead of using platinum which is very expensive metal with graphene, we should focus on non-noble metals with graphene because they can be synthesized in low cost as compare to the platinum and can give comparable electrocatalytic activity and stability.

\section{REFERENCES}

[1] Sharma, Surbhi, and Bruno G. Pollet. "Support materials for PEMFC and DMFC electrocatalysts - a review." Journal of Power Sources 208 (2012): 96-119.

[2] Badwal, S. P. S., et al. "Direct ethanol fuel cells for transport and stationary applications-A comprehensive review." Applied Energy 145 (2015): 80-103.

[3] Soo, Li Ting, et al. "An overview of the electrochemical performance of modified graphene used as an electrocatalyst and as a catalyst support in fuel cells." Applied Catalysis A: General 497 (2015): 198-210.

[4] Jang, Hee Dong, et al. "Three-dimensional crumpled graphene-based platinum-gold alloy nanoparticle composites as superior electrocatalysts for direct methanol fuel cells." Carbon 93 (2015): 869877.

[5] Ma, Junhong, et al. "Enhanced electrocatalytic activity of $\mathrm{Pt}$ nanoparticles supported on functionalized graphene for methanol oxidation and oxygen reduction." Journal of colloid and interface science 457 (2015): 102-107.

[6] Antolini, Ermete. "Graphene as a new carbon support for lowtemperature fuel cell catalysts." Applied Catalysis B: Environmental 123 (2012): 52-68.

[7] Huang, Huajie, et al. "Graphene nanoplate-Pt composite as a high performance electrocatalyst for direct methanol fuel cells." Journal of Power Sources 204 (2012): 46-52.

[8] Yu, Shuping, et al. "Graphene-CeO 2 hybrid support for $\mathrm{Pt}$ nanoparticles as potential electrocatalyst for direct methanol fuel cells." Electrochimica Acta94 (2013): 245-251.

[9] Chen, Maojun, et al. "PtCo nanoparticles supported on expanded graphite as electrocatalyst for direct methanol fuel cell." Electrochimica Acta 165 (2015): 105-109.

[10] Barakat, Nasser AM, and Moaaed Motlak. "Co x Ni y-decorated graphene as novel, stable and super effective non-precious electrocatalyst for methanol oxidation." Applied Catalysis B: Environmental 154 (2014): 221-231.

[11] Tao, Li, et al. "Simultaneous Pt deposition and nitrogen doping of graphene as efficient and durable electrocatalysts for methanol oxidation."International Journal of Hydrogen Energy 40.41 (2015): 14371-14377. 
[12] Guo, Jinxue, et al. "FePt nanoalloys anchored reduced graphene oxide as high-performance electrocatalysts for formic acid and methanol oxidation."Journal of Alloys and Compounds 604 (2014): 286-291.

[13] Kamaruddin, M. Z. F., et al. "An overview of fuel management in direct methanol fuel cells." Renewable and Sustainable Energy Reviews 24 (2013): 557-565.

[14] Ji, Kai, et al. "Efficient and clean synthesis of graphene supported platinum nanoclusters and its application in direct methanol fuel cell." Electrochimica Acta 85 (2012): 84-89.

[15] Vu, Thu Ha Thi, et al. "Solvothermal synthesis of Pt-SiO 2/graphene nanocomposites as efficient electrocatalyst for methanol oxidation."Electrochimica Acta 161 (2015): 335-342 